\title{
The Effect of Applying Knowledge Management in Hotels on Hotel Performance and Hotel Innovation
}

\author{
Ahmed Mustafa Mohammed Amin* \\ Farida Mohammed Megahed* Mohammed Abu Taleb Mohammed* \\ * Hotel studies department, University of Sadat City
}

\begin{abstract}
Knowledge management is becoming increasingly important in light of the major challenges that organizations face, and this is reinforced by the increasing importance of cognitive objectives that focus on knowledge management, leading to enhanced productivity, efficiency and effectiveness in organizations. The research investigates the effect of applying $\mathrm{KM}$ on the performance and innovation practices in five-star hotels. The questionnaire forms were distributed to five-star hotels in Luxor and Aswan cities, where 240 were distributed with 20 forms per hotel, of which about 200 were valid, $83.0 \%$ valid for analysis by The Statistical Program for the Social Science (SPSS) version 16 was used to analyze the questionnaire among its many modules for statistical data analysis, including Shapiro-Wilk test of the normality, the mean, standard deviation, alpha Cronbach's test, Mannwhitney and the KruskalWallis test, spearman correlation and simple linear regression. The findings showed that there is a significant relationship between knowledge management and hotel performance. Results also showed that there is a significant relationship between knowledge management and hotel innovation.
\end{abstract}

Keywords: Knowledge, Knowledge Management, Hotel innovation, Hotel performance, Hotel Employees.

\section{Introduction}

Knowledge Management (KM) appeared on the scene of management researchers just after "Learning Organization" in 1990. Learning organization is defined as an organization talented at creating, acquiring and transferring knowledge and modifying its behavior to reflect new knowledge and insights (Özorhon, 2004). The rapid development of information and communication technology (ICT) and the rapid increase of new tools like intranet and groupware systems facilitated the information exchange among both individuals and groups.

The main motivation behind KM expansion during the last two decades is due to the globalization and high competition, improvement in new information and communication technologies (Anumbaet al., (2005)). From the academic point of view, theoretical developments like resource-based and knowledgebased views of the firms, which emphasize the importance of unique and inimitable assets called tacit knowledge served for the necessity and importance of KM to overall hospitality industry(Egbu, 2000). The main driver behind the increasing interest of KM was the fact that knowledge was seen as an asset for the organization similar to other physical assets (Wiig, 1999). 
Darroch and McNaughton (2002) stated that the hospitality industry is related to knowledge management in the field of worker's knowledge, information technology, relationships with stakeholders, management philosophy and so on. Various studies have reported consequences of effective KM . It creates some kinds of competitive advantage, enhances performance, enables a company to be more innovative, allows a company to better anticipate problems and it enables a company to better analyze and evaluate information.The study investigates the effect of applying KM on the performance and innovation practices in five-star hotels. The findings showed that there is a significant relationship between knowledge management and hotel performance.

\section{Literature review}

\subsection{Knowledge management: definition and background}

KM is described by American Productivity and Quality Center (APQC) as a systematic approach (integrating people, processes, technology, and content) to enable information and knowledge to be created and flow to the right people at the right time so that their work and decisions can add value to the mission of the organization (Leawitt, 2003). Knowledge management is defined as

Knowledge management isconsidered one of the most important parts of any organization and a complement to the hospitality activities. With new economy, knowledge is getting the most important asset for organizational success among other assets such as capital, materials, machineries, and properties (Wong et al, 2004).

\subsection{The objectives of knowledge management}

Goswami (2008) explained that the objective of knowledge management is to capture tacit knowledge of different stakeholders of the organization as customers, shareholders, employees, suppliers etc. and make it explicit so that other employees can take advantage of it. Such sharing of information will enable improved and quicker decision making and benefit the organization. The reason for different and various definitions about knowledge management is that some definitions focus on knowledge management processes and some of consider to the aim .

The knowledge management confirms the principle of culture cognitive and update knowledge on an ongoing basis and designed to facilitate teamwork and transforming knowledge into viable way to use through the acquisition and vocational based control and control on the management of knowledge, such as the formation of a database and information operations, as well as generating the necessary knowledge to achieve the learning processes and deployments knowledge to all relevant parties, as it contributes to raising the performance of the staff base by providing them with integrated it and wrong help them to raise their efficiency and develop their abilities which leads to increased production and profits (Nonaka, 1991). 
One of the most important objectives of $\mathrm{KM}$ is to bring together intellectual resources and make them available across organizational boundaries. It has been suggested that organizations often waste their resources and lose projects and being unaware of each other's' knowledge due to the lack of knowledge transfer and sharing throughout the organization (Robertson, 2002) .

According to Malhotra (2000) Knowledge management embodies organizational processes that seek to combine data and information processing capacity with information technologies, creative and creative capacity of human beings and require a rethinking of everything in the organization and addressing critical issues of organizational adaptation, survival and efficiency in the face of increased intermittent environmental change.KM provide the tools and services for guests to capture, share, reuse, update, and create new experiences, problem solutions and best practices to aid employees in processes such as problem solving, decision making and innovation, and so to enhance the total performance of the organization (Ahmad et al., 2007).

\subsection{Knowledge Management Infrastructure}

KM infrastructure capabilities are the overall organizational activities or mechanisms that can stimulate knowledge creation, protect knowledge, and facilitate the sharing of knowledge in an organization (Lee et al.,2003). In other words, they refer to modular products and organizational designs which enable KM activities in an organization (Sanchez and Mahoney,1996).KM incorporates three main dimensions: organizational culture,people, and information technology (Goldet al.,2001; Lee and Choi ,2003).

\subsubsection{Organizational Culture}

The organizational culture has a fundamental role in knowledge management. Organizations tend to develop dominant organizational cultures over time as the organizations adapt and respond to the challenges and changes in the environment. In light of the above, culture and structure could be essential or major feedback in KM for organizations in the hospitality industry(Migdadi, 2005). Yoopetck (2010) indicated that organization culture describes the degree to which organization culture provides support for viewing knowledge as valuable assets .Culture resources is considered the most important factor for successful KM. For example, dialogue between individuals or groups is often the basis for the creation of new ideas and can, therefore, be viewed as having the potential for creating knowledge.

\subsubsection{People}

People of organizations are recognized to be the key enabler in successful KM. Since knowledge resides in people's minds, human resources are at the heart of creating organizational knowledge. In addition, human interaction is the critical source of intangible value in the intellectual age (O'Donnelet al., 2003). 
Holsapple and Joshi (2001) stated that HR practices are used to motivate employees' willingness and commitments to acquire, share, and apply knowledge within organizations when developing KM. Thus, appropriate HR practices can support and promote the development of an organizational environment conducive to KM work. Human resource describes the extent to which employees specialize in a particular domain and demonstrate the capability of applying that knowledge to interact with others. The human resource is at the heart of creating knowledge resources. Holsapple and Joshi reported that HR practices have a positive impact on knowledge management.

\subsubsection{Information Technology}

Yoopetck (2010) mentioned that Information Technology is relevant to KM for two fundamental reasons. First, information systems are now essential for the storage and retrieval of information and explicit knowledge, second, Information Technology is particularly useful in overcoming the barriers of distance and time and in enabling collaborative teamwork, knowledge sharing and integration (Chesbrough and Teece, 1996). According to James (2005), information technology is related to $\mathrm{KM}$ as the availability and advances in technological capability have often resulted in reductions in staffing levels which, unless it is carefully and effectively managed, can result in loss of knowledge within organizations

\subsection{Benefits and Barriers of Applying Knowledge Management in Hotels}

Cooper (2006) stated that many scholars believe that the KM approach is a crucial tool for hospitality and tourism companies wishing to gain competitive advantages. In the light of rapid changes to the economy, hospitality and tourism companies are facing serious problems such as increasing operating uncertainty, changing customer preferences, shorter service product life cycles, and complicated intrusive constraints. Knowledge management is an important solution to those problems.

Scott and Laws (2006) reported that applying knowledge management improves business performance and meet the hotel missions. As a result, it is important to establish the connection between business strategy and knowledge management in the early planning stages to apply knowledge management system in all hospitality operations and plans. In this way, the best possible knowledge can be made available at every level of activity (Wiig, 1999).

On the other hand, Cooper (2006) stated that cost and time are two barriers to the application of knowledge management. The knowledge management process requires a change in management and companies have to put a huge amount of money into the process and wait for the results. Hospitality and tourism organizations are kept busy with daily jobs, and may not have time for identifying and planning from the available knowledge. Although it is easy to accumulate information in hospitality and tourism organizations, employees and managers, especially those from small and midsize companies, cannot easily derive the relevant information from all the information which are available to them (Gupta and McDaniel, 2002). 


\subsection{Accordingly the following hypothesis is formulated:}

\subsubsection{H1: There is a statistically significant relationship between knowledge management and hotel performance.}

Hotel performance can be improved by locating and sharing useful knowledge and the potential for knowledge management to create competitive advantage is positively linked to organizational performance (Schulz and Jobe, 2001). Liao et al. (2010) reported that the overall performance of the hotel depends on the extent to which managers can mobilize all of the knowledge management resources that are held by individuals and teams and turn these resources into value-creating activities.

Tallonet al. (2000) stated that the perceptual measures of hotel performance strongly correlate with more traditional objective measures including sales growth, net income growth, and return on investment. Kim and Hancer (2010) studied the effect of knowledge management resource inputs on hotel performance in the hospitality industry. The results revealed that the significant knowledge management resource inputs that affected hotel performance was information technology, incentive, and a knowledge-sharing culture. Information technology turns out to be the most important input that is followed by incentive and a knowledge-sharing culture to improve hotel performance.

\subsubsection{H2: There is a statistically significant relationship between knowledge management and hotel Innovation}

Chen and Huang (2009) stated that hotel must constantly undergo innovation. This innovation requires a well-planned knowledge management capability that will enable the hotel to excel in knowledge-based interactions. Several definitions of innovation were identified; among those is the one presenting innovation as the adoption of an idea or behavior, whether a system, policy, program, device, process, product or service. Gopalakrishnan (2000) found that innovation comprises the speed and magnitude, and this categorization provides an effective method of investigating the link between innovation and hotel performance. Innovation speed reflects a quickness of hotel to generate a product or process relative to its competitors within the industry. Innovation magnitude refers to the degree to which hotel generates a number of new ideas, products, processes, or services relative to its competitors within the industry.

\section{Methodology}

\subsection{Population and sample}

The aim of this study is to examine the Effect of applying KM on The Performance and Innovation Practices in Five Stars Hotels. According to the Egyptian Hotel Association (EHA) (2016), there are 12 five-star hotels in Luxor and Aswan. The reason for choosing this category is that these hotels apply practices and policies of management more developed than any other type of hotels. 
A questionnaire was developed to investigate the effect of applying KM on the hotel performance and innovation practices in five-star hotels in Luxor and Aswan cities. It was divided into four sections. The first section included the respondents' demographics and some related work data. The second section investigated KM. It was divided into two subsections. The first one consisted of eight items representing KM organizational culture factors among the employees. The second subsection contained eight items with the aim to know the availability of information technology in accessible to all employees. This section was designed based on Gold et al. (2001) and Grover and Davenport 2001) studies. The third part of the questionnaire was designed to measure the hotel performance. This measure has been developed and validated by Liao et al. (2010) and Gopalakrishnan (2000). This section comprised fifteen items to know the impact of applying knowledge management on the employees' performance in the hotel. The last part of the questionnaire was designed to measure hotel innovation. The measure has been adapted from Uhlaner et al. (2007) and Deshpandeel al. (1993). It contained eight items to measure the impact of applying knowledge management on the innovation practices in the hotel.

A sample of employees working in the in five-star hotels was chosen to carry out the current study. The questionnaire forms were distributed to five-star hotels in Luxor and Aswan cities, where 240 were distributed with 20 forms per hotel, of which 200 were valid for analysis with $83.0 \%$ response rate. The investigated hotels and the number of distributed questionnaire forms are shown in table (1).

Table (1): Number of questionnaire forms distributed in each hotel

\begin{tabular}{|l|l|l|l|}
\hline \multirow{2}{*}{ Hotel name } & \multirow{2}{*}{$\begin{array}{l}\text { N.O of } \\
\text { forms }\end{array}$} & \multicolumn{2}{c|}{ Valid forms } \\
\cline { 3 - 4 } & & NO. & percentage \\
\hline \multicolumn{1}{|c|}{ Hilton Luxor Hotel SPA } & 20 & 17 & $85 \%$ \\
\hline Luxor Sheraton hotel Resort & 20 & 18 & $90 \%$ \\
\hline $\begin{array}{l}\text { Maritim Jolie ville kings island } \\
\text { resort }\end{array}$ & 20 & 15 & $75 \%$ \\
\hline Sofitel Karnack hotel & 20 & 16 & $80 \%$ \\
\hline Sofitel Winter palace hotel & 20 & 18 & $90 \%$ \\
\hline Sonesta st George hotel & 20 & 16 & $80 \%$ \\
\hline Stiegen Berger Nile palace hotel & 20 & 19 & $95 \%$ \\
\hline Amoun Village & 20 & 15 & $75 \%$ \\
\hline Move pick Resort Aswan & 20 & 16 & $80 \%$ \\
\hline New cataract Hotel & 20 & 17 & $85 \%$ \\
\hline Pyramis Asis island hotel & 20 & 18 & $90 \%$ \\
\hline Sofitel old cataract hotel & 20 & 15 & $75 \%$ \\
\hline Total & 240 & 200 & $83.0 \%$ \\
\hline
\end{tabular}

Source: Egyptian Hotel Association (2016). 


\subsection{Data Analysis}

The Statistical Program for the Social Science (SPSS) version 16 was used to analyze the questionnaire among its many modules for statistical data analysis, including Shapiro-Wilk test of the normality, the mean, standard deviation, alpha Cronbach's test, Mannwhitney and the Kruskal- Wallis test, spearman correlation and simple linear regression.

\section{Results and Discussion}

\subsection{Validity and Reliability}

Cronbach's Alpha coefficient was calculated to determine the internal consistency of the scale. The computation of Cronbach's Alpha is based on the number of items on the survey and the ratio of the average inter-item covariance to the average item variance. Reliability coefficient of 0.7 or higher is considered "acceptable" in most social science research situations. Thus, the Cronbach's Alpha reliability was computed, and the coefficient calculated was more than 0.7 for all Scales as shown in table (2).

Table (2): Validity and Reliability

\begin{tabular}{|l|c|c|}
\hline Scale & Number of items & Cronbach's Alpha \\
\hline Organization Culture & 8 & 0.95 \\
\hline $\begin{array}{l}\text { Information } \\
\text { Technology }\end{array}$ & 8 & 0.84 \\
\hline Hotel Performance & 15 & 0.78 \\
\hline Hotel Innovation & 8 & 0.91 \\
\hline All questionnaire & 39 & 0.93 \\
\hline
\end{tabular}

An assessment of the normality of data is a prerequisite for many statistical tests because normal data is an underlying assumption in parametric testing. Well-known test of normality, namely the Shapiro-Wilk test, was used. The pvalue was less than 0.05 as shown in table (3). Thus, it can be concluded that the distribution of the data deem to be not normal. As a result, non-parametric tests were used.

Table (3): Shapiro-Wilk test of the normality

\begin{tabular}{|l|c|c|}
\hline \multicolumn{1}{|c|}{ Item } & Shapiro-Wilk & Sig. \\
\hline Organization Culture & 0.894 & 0.000 \\
\hline Information Technology & 0.872 & 0.000 \\
\hline Hotel Performance & 0.859 & 0.000 \\
\hline Hotel Innovation & 0.843 & 0.000 \\
\hline
\end{tabular}




\subsection{Respondents' demographic profile}

The demographic profiles of the respondents are shown in table (4). It was found that out of the 200 respondents, $81.5 \%$ of the sample was male and $18.5 \%$ were female. This result might reflect a high participation of males compared to females in the hotels of the study. Males might be more motivated and willing for working in the hotels of the study. According to educational field of the respondents, hospitality management field represent $77.5 \%$, while others represents $22.5 \%$ of the population.

Table (4): Respondents demographic data

\begin{tabular}{|l|c|c|}
\hline Gender & Frequency & Percent \\
\hline Male & 163 & 81.5 \\
\hline Female & 37 & 18.5 \\
\hline Total & 200 & 100.0 \\
\hline Educational field & Frequency & Percent \\
\hline Hospitality management field & 155 & 77.5 \\
\hline Others & 45 & 22.5 \\
\hline Total & 200 & 100.0 \\
\hline
\end{tabular}

\subsection{Respondents' work related information}

Table (5) shows some work related information of the hotel respondents which revealed that the majority of the hotels was chain management $(90.0 \%)$, while independently managed represents $20(10.0 \%)$ of the population. In terms of work area of respondents, table (7) showed that $(178,88 \%)$ worked in human resources department, $(5,2.5 .0 \%)$ worked in front office department and $4(2.0 \%)$ worked in food and beverage department. Also, there are $15(7.5 \%)$ respondents worked in other departments such as kitchen and room service.

Table: (5) Respondents work related information

\begin{tabular}{|l|c|c|}
\hline Management type & Frequency & Percent \\
\hline Chain Managed & 180 & 90.0 \\
\hline Independently Managed & 20 & 10.0 \\
\hline Total & 200 & 100.0 \\
\hline Department & Frequency & Percent \\
\hline Front Office & 5 & 2.5 \\
\hline Restaurant & 4 & 2.0 \\
\hline Human Resources & 176 & 88.0 \\
\hline Others & 15 & 7.5 \\
\hline Total & 200 & 100.0 \\
\hline
\end{tabular}

\subsection{Respondents' attitude towards study variables}

The overall mean value of (Organization culture) was 3.65 and the overall standard deviation was 1.13. This means that the respondents accepted the items. The overall mean value of (Information Technology) was 4.29 and the standard deviation was 0.458 . This means that the respondents accepted all items. The mean value of (Hotel Performance) was 4.42 and the overall standard deviation was 0.45 . 
This means that the respondents accepted items. The overall mean value of (Hotel innovation) was 4.41 and the overall standard deviation was 0.48 . This means that the respondents accepted items as shown in table (6).

Table (6) Respondents' attitude towards the applying of the Knowledge management in hotels

\begin{tabular}{|l|l|l|l|}
\hline No. & Items & Mean & SD \\
\hline 1- Knowledge management & $\mathbf{3 . 9 1}$ & $\mathbf{. 7 1}$ \\
\hline \multicolumn{2}{|c|}{ A. Organization culture } & $\mathbf{3 . 6 5}$ & $\mathbf{1 . 1 3}$ \\
\hline \multicolumn{2}{|c|}{ B. Information Technology } & $\mathbf{4 . 2 9}$ & $\mathbf{. 4 5 8}$ \\
\hline 2 & Hotel performance & $\mathbf{4 . 4 2}$ & $\mathbf{. 4 5}$ \\
\hline 3 & Hotel innovation & $\mathbf{4 . 4 1}$ & $\mathbf{. 4 8}$ \\
\hline
\end{tabular}

\subsection{The correlation between study variables}

The results indicated that, there is a significant correlation between the independent variables which include organization culture and information technology (knowledge management) and the dependent variables which include hotel performance and hotel innovation as the following:

1- There is a significant correlation between the organization culture and hotel performance (the correlation value $=0.358$ ).

2- There is a significant correlation between organization culture and hotel innovation (the correlation value $=0.339$ ).

3- There is a significant correlation between information technology and hotel performance (the correlation value $=0.723$ ).

4- There is a significant correlation between information technology and hotel innovation (the correlation value $=0.661$ ).

All the above relationships can be summarized in figure (1).

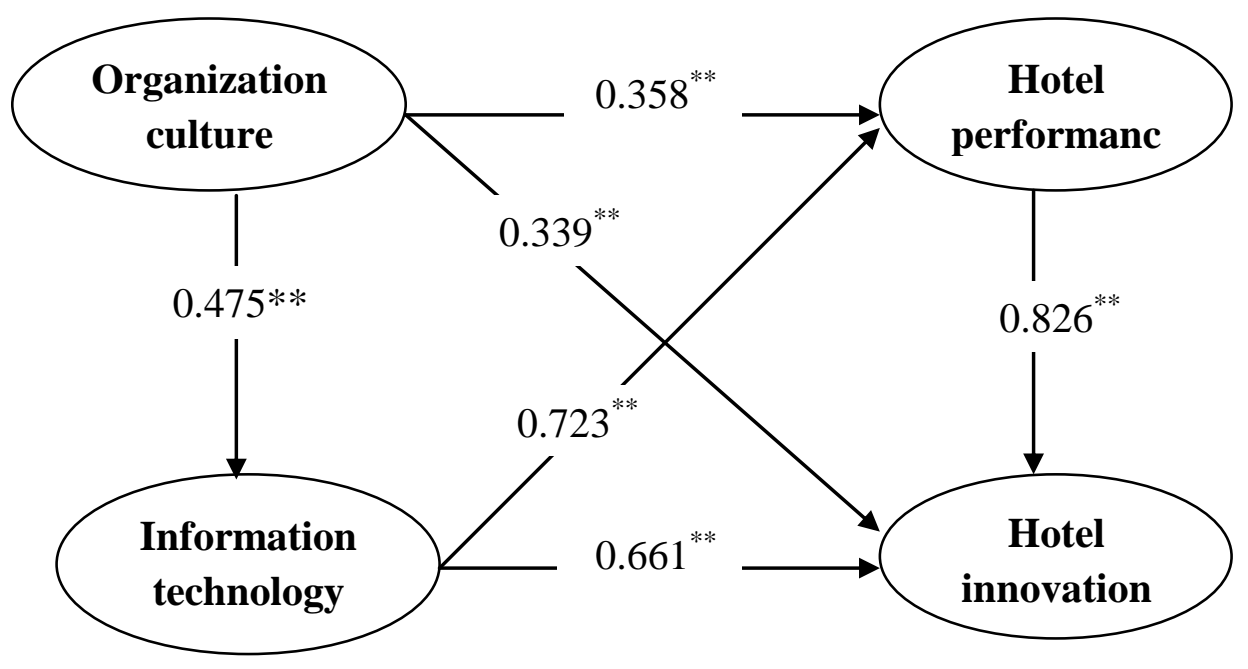

Figure (1): The correlation between the variables of the study 


\subsection{Effect of knowledge management on hotel performance}

Hotel performance can be improved by locating and sharing useful knowledge and the potential for KM to create competitive advantage is positively linked to organizational performance (Schulz and Jobe, 2001). Liao et al. (2010) stressed that the overall performance of the hotel depends on the extent to which managers can mobilize all of the knowledge management resources that are held by individuals and teams and turn these resources into value-creating activities.

The results in Table (10) indicated that, the existence of a relationship between the independent variable (knowledge management) and the dependent variable (hotel performance) was supported. Moreover, the model suggests that, the knowledge management explains roughly $20 \%$ of the variation in hotel performance.

Table (10): Effect of knowledge management on hotel performance

\begin{tabular}{|c|c|c|c|c|c|c|}
\hline \multirow[t]{2}{*}{ Model } & \multicolumn{2}{|c|}{$\begin{array}{l}\text { Un standardized } \\
\text { Coefficients }\end{array}$} & $\begin{array}{c}\text { Standardized } \\
\text { Coefficients }\end{array}$ & \multirow{2}{*}{$\begin{array}{c}\text { Adjusted R } \\
\text { square }\end{array}$} & \multirow[t]{2}{*}{$\mathrm{t}$} & \multirow[t]{2}{*}{ Sig. } \\
\hline & B & Std. Error & Beta & & & \\
\hline (Constant) & 3.295 & 0.162 & & & 20.353 & .000 \\
\hline $\begin{array}{l}\text { Knowledge } \\
\text { management }\end{array}$ & 0.287 & 0.041 & 0.452 & 0.200 & 7.042 & .000 \\
\hline
\end{tabular}

*Dependent Variable: Hotel performance

The regression formula was:

\section{Hotel performance $=3.295+0.287 *$ Knowledge management}

\subsection{Effect of knowledge management on hotel innovation}

Uhlaneret al. (2007) indicated that for that firms implementing KM grow more quickly than the others. Chen and Huang (2009) stated that if hotel objective is to become the most innovative firm in the world, this necessitates the effective use of KM. various studies focus on the role of KM in the innovation process. The results that are found by Liao and Chuang (2006) confirmed the vital role that KM plays for the knowledge-processing capability and in turn, on speed and activity of innovation.

The results in Table (8) indicated that, the existence of a relationship between the independent variable (knowledge management) and the dependent variable (hotel innovation) was supported. Moreover, the model suggests that, the knowledge management explains roughly $19.7 \%$ of the variation in hotel performance. 
Table (8): Effect of knowledge management on hotel Innovation

\begin{tabular}{|c|c|c|c|c|c|c|}
\hline \multirow[t]{2}{*}{ Model } & \multicolumn{2}{|c|}{$\begin{array}{c}\text { Un } \\
\text { standardized } \\
\text { Coefficients }\end{array}$} & \multirow{2}{*}{$\begin{array}{c}\begin{array}{c}\text { Standardized } \\
\text { Coefficients }\end{array} \\
\text { Beta }\end{array}$} & \multirow{2}{*}{$\begin{array}{c}\text { Adjusted R } \\
\text { square }\end{array}$} & \multirow[t]{2}{*}{$\mathrm{t}$} & \multirow[t]{2}{*}{ Sig. } \\
\hline & B & $\begin{array}{l}\text { Std. } \\
\text { Error }\end{array}$ & & & & \\
\hline (Constant) & 3.227 & 0.173 & & & 18.646 & .000 \\
\hline $\begin{array}{l}\text { Knowledge } \\
\text { management }\end{array}$ & 0.303 & 0.044 & 0.449 & 0.197 & 6.957 & .000 \\
\hline
\end{tabular}

*Dependent Variable: Hotel innovation

The regression formula was:

\section{Hotel innovation $=3.227+0.303 *$ Knowledge management}

4.8 Differences between employees' demographic variables towards knowledge management application

Results in table $(9,10,11,12,13,14)$ showed that there are significant differences among respondents' opinions between their personal profile (gender, age, management type, education level, and department) and the application of knowledge management. On the other hand, there were no significant differences between respondents' experiences and the application of knowledge management.

Table (9) Differences among respondents' opinions towards knowledge management application depending on gender

\begin{tabular}{|c|c|c|c|}
\hline \multicolumn{2}{|c|}{ Mean Rank } & \multirow{2}{*}{$(\mathbf{z})$} & \multirow{2}{*}{$\begin{array}{c}\text { Sig. } \\
\text { (p. Value) }\end{array}$} \\
\hline Male & Female & & 0.001 \\
\hline $\mathbf{1 0 5 . 2 5}$ & 69.49 & -3.471 & \\
\hline
\end{tabular}

*Significant at the 0.05 or less.

Table (10) Differences among respondents' opinions towards knowledge management application depending on age

\begin{tabular}{|c|c|c|c|c|}
\hline \multicolumn{3}{|c|}{ Mean Rank } & \multirow{2}{*}{$\left(\mathbf{x}^{\mathbf{2}}\right)$} & $\begin{array}{c}\text { Sig. } \\
\text { (p. Value) }\end{array}$ \\
$\begin{array}{c}\text { Less } \\
\text { than 25 } \\
\text { years }\end{array}$ & $\begin{array}{c}\text { From 25 to 40 } \\
\text { years }\end{array}$ & $\begin{array}{c}\text { More than 40 } \\
\text { years }\end{array}$ & & 0.000 \\
\hline $\mathbf{6 5 . 9 1}$ & 109.44 & 58.47 & 24.179 & 0 \\
\hline
\end{tabular}

*Significant at the 0.05 or less. 
Table (11) Differences among respondents' opinions towards knowledge management application depending on education level

\begin{tabular}{|c|c|c|c|c|}
\hline \multicolumn{3}{|c|}{ Mean Rank } & \multirow[b]{2}{*}{$\left(\mathrm{x}^{2}\right)$} & \multirow{2}{*}{$\begin{array}{c}\text { Sig. } \\
\text { (p. Value) }\end{array}$} \\
\hline $\begin{array}{l}\text { Secondary } \\
\text { school } \\
\text { education }\end{array}$ & $\begin{array}{l}\text { University or } \\
\text { equivalent } \\
\text { qualification }\end{array}$ & Other & & \\
\hline 63.59 & 102.92 & 102.79 & 9.475 & 0.009 \\
\hline
\end{tabular}

*Significant at the 0.05 or less.

Table (12) Differences among respondents' opinions towards knowledge management application depending on experience

\begin{tabular}{|c|c|c|c|c|c|}
\hline \multicolumn{4}{|c|}{ Mean Rank } & \multirow[b]{2}{*}{$\left(\mathrm{x}^{2}\right)$} & \multirow[b]{2}{*}{$\begin{array}{c}\text { Sig. } \\
\text { (p. Value) }\end{array}$} \\
\hline $\begin{array}{l}\text { Less than } \\
1 \text { year }\end{array}$ & $\begin{array}{c}1 \text { year to } 5 \\
\text { years }\end{array}$ & 6-10 years & $\begin{array}{c}\text { More } \\
\text { than } 10 \\
\text { years }\end{array}$ & & \\
\hline 65.31 & 102.41 & 88.40 & 88.50 & 7.264 & 0.064 \\
\hline
\end{tabular}

*Significant at the 0.05 or less.

Table (13) Differences among respondents' opinions towards knowledge management application depending on management type

\begin{tabular}{|c|c|c|c|}
\hline \multicolumn{2}{|c|}{ Mean Rank } & \multirow{2}{*}{$(\mathbf{z})$} & \multirow{2}{*}{$\begin{array}{c}\text { Sig. } \\
\text { (p. Value) }\end{array}$} \\
\cline { 1 - 2 } $\begin{array}{c}\text { Chain } \\
\text { Managed }\end{array}$ & $\begin{array}{c}\text { Independently } \\
\text { Managed }\end{array}$ & & 0.017 \\
\hline $\mathbf{1 0 1 . 2 6}$ & 69.48 & -2.398 & 0.48 \\
\hline
\end{tabular}

*Significant at the 0.05 or less.

Table (14) Differences among respondents' opinions towards knowledge management application depending on department

\begin{tabular}{|c|c|c|c|c|c|}
\hline \multicolumn{4}{|c|}{ Mean Rank } & \multirow{2}{*}{$\left(\mathbf{x}^{2}\right)$} & \multirow{2}{*}{$\begin{array}{c}\text { Sig. } \\
(\mathbf{p} . \\
\text { Value) }\end{array}$} \\
\hline $\begin{array}{l}\text { Front } \\
\text { office }\end{array}$ & Restaurant & $\begin{array}{c}\text { Human } \\
\text { resources }\end{array}$ & Other & & \\
\hline 79.00 & 67.38 & 102.96 & 62.20 & 9.086 & 0.028 \\
\hline
\end{tabular}

*Significant at the 0.05 or less. 


\section{5-Conclusion and implications}

$\mathrm{KM}$ is the name given to the set of procedures that an organization can take to get the maximum value from the knowledge available to it. Effective KM normally requires a proper incorporation of organizational, social, and managerial initiatives along with utilization of apposite technology .The research investigates the effect of applying $\mathrm{KM}$ on the performance and innovation practices in five-star hotels.

Then, there is a need to enhance awareness of hotel employees about the importance of applying knowledge management to help in categorizing captured knowledge, finding required knowledge and providing idea of applying knowledge management requirements. Hotels management should direct some of their budgets to provide staff with continuous training about knowledge management models because employees who see benefit in KM have a hard time to change their culture accordingly.

The research concluded that before allocating any resources into the knowledge sharing schemes, managers must establish a common KM strategy by developing a unified understanding of knowledge management functions within the hotel. Finally, the exponential growth of knowledge assets has holistic influence on hotel culture and operations. Thus, the proposed actions aiming at developing, optimizing, and rationalizing $\mathrm{KM}$ at hotels will bring both short- and long-term benefits.

Hotel management should build up an organizational design that enables the creation of new knowledge, knowledge exchange and transfer across functional boundaries. At the same time, knowledge needs to be frequently examined for mistakes. Hotels should clearly support the role of knowledge in department success, make sure that their employees understand this issue and more importantly encourage them to participate in on-the-job training and learning as well as in capturing and transferring knowledge.

Hotels should establish a special Knowledge Center collecting the information about customers, markets, competitors or any other useful information from internal and external sources, then treating, analyzing, and making it available to other departments. Hotels managers should be aware of the critical role of the capacity to effectively applied integrated knowledge resources to the creation and delivery of products and services to customers, assisting hotels to improve organizational performance and innovation.

Finally, hotel should focus on: (1) Staff as a key element in the share of knowledge, through effective incentive system focuses on the physical and moral side, (2) Tacit knowledge, especially knowledge in the minds of individuals and the need for documented so that they become part of the organizational memory and (3) Informal contacts between employees and senior management to facilitate the share of knowledge. 


\section{References}

Ahmad, H. S., An, M. and Gaterell, M. (2007) „Development of KM model to simplify knowledge management implementation in construction projects ${ }^{\text {ee }}$, Proceedings of the 23rd Annual ARCOM Conference, Association of Researchers in Construction Management,

Anumba, C., Egbu, C. and Carrillo, P. (2005).Knowledge Management in Construction.Oxford, UK,First Edition, Blackwell PublishingLtd., pp.21-25, 84-88.

Chen, C. and Huang, J. (2009).Strategic Human Resource Practices and Innovation Performance - The Mediating Role of Know-ledge Management Capacity. Journal of Business Research, 62(1), pp.104-114.

Chesbrough, H. and Teece, D. (1996). Organizing for Innovation: When is Virtual Virtuous?. USA, Harvard Business Review and Harvard Business Publishing Newsletter.

Cooper, C. (2006). Knowledge Management and Tourism.Annals of Tourism Research, 33(1), pp.47-64.

Darroch, J. and McNaughton, R. (2002). Examining the link between Knowledge Management Practices and Types of Innovation. Journal of Intellectual Capital, 3(3), pp. 210-222.

Deshpande, R., Farley, J. and Webster, F. (1993). Corporate Culture, Customer Orientation and Innovativeness in Japanese Firm, a Quadrad Analysis.Journal of Marketing, 57(1), pp. 23-37

EHA, (Egyptian Hotel Association).(2016). The Egyptian Hotel Guide, Thirty three Edition, ETF, Cairo, pp.44-48.

Gold, A., Malhotra, A. and Segars, A. (2001). Knowledge Management: An Organizational Capabilities Perspective. Journal of Management Information Systems, 18(1), pp. 185-214.

Gopalakrishnan, S. (2000). Unraveling the Links between Dimensions of Innovation and Organizational Performance. Journal of High Technological Management Research, 11(1), pp. 137-153.

Goswami, C. (2008)" "Knowledge Management in India: A Case Study of An Indian Bank", The Journal of Nepalese Business Studies, Vol. V No. 3, pp: $37-$ 49.

Grover, V. and Davenport, T. (2001). General Perspectives on Knowledge Management: Fostering a Research Agenda. Journal of Management Information Systems, 18(1), pp. 5-21.

Gupta, A. and McDaniel, J. (2002). Creating Competitive Advantage by Effectively Managing Knowledge: A Framework for Knowledge Management. Journal of knowledge management Practice, 3(1), pp.44-50. 
Holsapple, C. and Joshi, K. (2001).Organizational Knowledge Resource.Decision Support System, 31(1), pp. 39-54.

James, P. (2005). Knowledge Asset Management: The Strategic Management and Knowledge Management Nexus. (DBA) thesis, Southern Cross UniversityLismore, NSW, Australia.

Kim, Y. and Hancer, M. (2010). The Effect of Knowledge Management Resource Inputs on Organizational Effectiveness in the Restaurant Industry. Journal of Hospitality and Tourism Technology, 1(2), pp. 174-189.

Leawitt, P. (2003). Using knowledge management to drive innovation. USA, Texas: American Productivity \& Quality Center Publications.

Lee, H. and Choi, B. (2003). Knowledge Management Enablers, Processes, and Organizational Performance: An Integrative View and Empirical Examination. Journal of Management Information Systems, 20(1), pp. 179-228.

Liao, C., Wang, H. and Chuang, S. (2010). Enhancing Knowledge Management for R\&D Innovation and Firm Performance: anintegrative view. African Journal of Business Management, 4(14), pp. 3026-3038.

Malhotra, Y. (2000) "Knowledge Management for E-Business Performance: Advancing Information Strategy to Internet Time." Information Strategy: The Executive's Journal, pp.5-16.

Migdadi, M. (2005).An Integrative View and Empirical Examination of the Relationships among Knowledge Management Enablers, Processes, and Organizational Performance in Australian Enterprises.(PHD) thesis, Faculty of commerce, University of Wollongong, Australian

Nonaka, I. (1991) “The knowledge-creating company", Harvard Business Review, Vol. 69, Issue 6, pp. 96 - 104.

Özorhon, B. (2004). Organizational Memory in Construction Companies: A Case-Based Reasoning Model as an Organizational Learning Tool. (Master) Thesis of the graduate school of natural and applied sciences of the Middle East technical university, Turkey.

O'Donnel, D., O'Regan, P., Coates, B., Kennedy, T., Keary, B.andBerkery, G. (2003). Human Interaction: The Critical Source of Intangible Value. Journal of Intellectual Capital, 4(1), pp. 82-99.

Robertson, S. (2002) "A Tale of Knowledge-Sharing Systems". Journal of Knowledge Management, Vol. 6, No. 3, pp.295-308.

Schulz, M. and Jobe, L. (2001). Codification and Tacitness as Knowledge Management Strategies: An Empirical Exploration. The Journal of High Technology Management Research, 12(1), pp. 139-165.

Scott, N., \& Laws, E. (2006).Knowledge sharing in tourism and hospitality .Journal of Quality Assurance in ospitality\& Tourism, 7(1), 1-12.

Tallon, P., Kraemer, K. and Gurbaxani, V. (2000). Executives' Perceptions of the Business Value of Information Technology: A Process-Oriented Approach. Journal ofManagement Information System, 16(4), pp.145173. 
Uhlaner, L., Stel, A., Van, S., Meijaard, J. and Folkeringa, M. (2007).The Relationship between Knowledge Management, Innovation and Firm Performance: Evidence from Dutch Smss, Scientific Analysis of Entrepreneurship and Smes. The Netherlands Ministry of Economic, the SCALES-initiative.http://www.entrepreneurship-sme.eu/ (accessed 13 May 2015).

Wiig, K. (1999). What Future Knowledge Management Users May Expect. Journal of Knowledge Management, 3(2), pp. 65-120.

Wong, K. and Aspinwall, E. (2004).Characterizing Knowledge Management in the Small Business Environment. Journal of Knowledge Management, 8(3), pp. 44-61.

Yoopetck, C. (2010). The model of Knowledge Acquisition: The study of SMEs in the Thai Hospitality Industry. World Academy of Science, Engineering andTechnology, 42(1), pp.351-360.

\section{أثر تطبيق إدارة المعرفة فى الفنادق على تطوير الأداء والابتكار بالفندق}

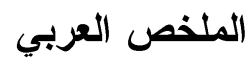

تهدف هذه الدراسة إلى استكثاف تطبيق إدارة المعرفة في فنادق الخمس نجوم بالأقصر وأسوان و أثر أثر

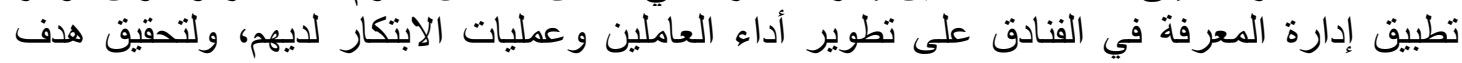

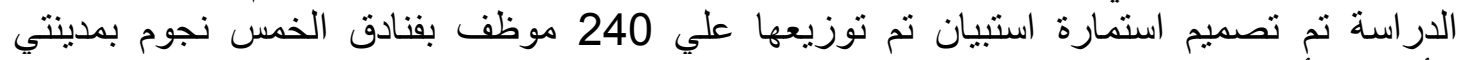

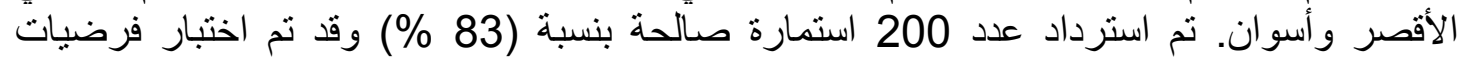
الدراسة عن طريق برنامج الحزم الإحصائية للعلوم الإجتماعية (SPSS) الإصدار 16 إندار 16 لتحليل

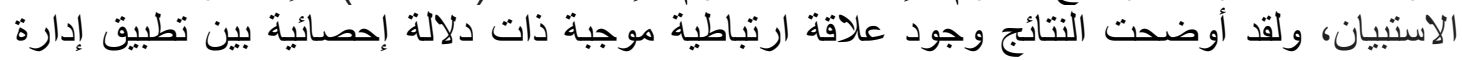

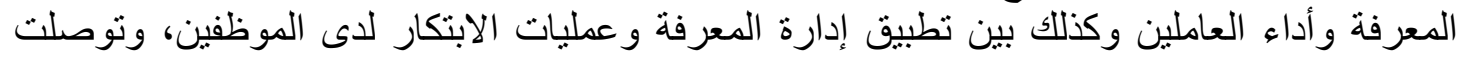

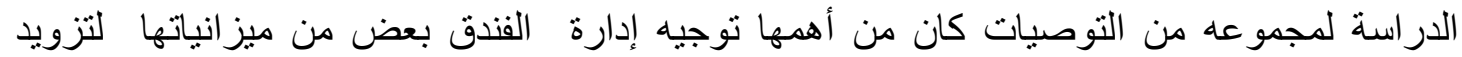

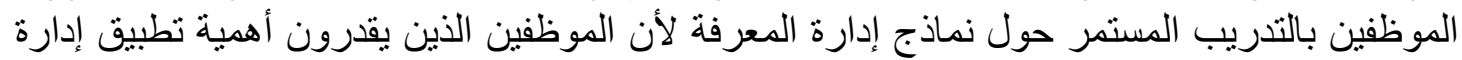

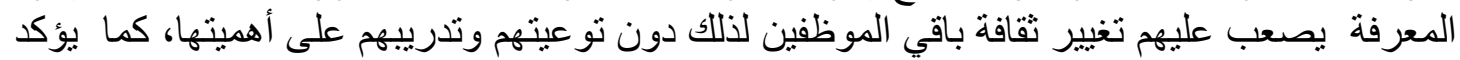

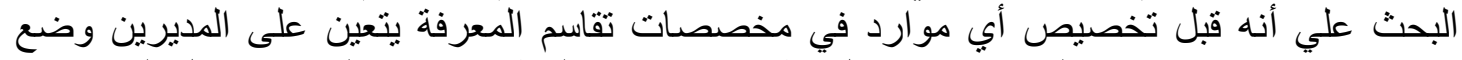

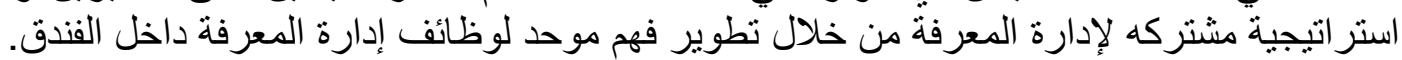

